\title{
Correlation of cadmium shell-weight index with environmental stress indicators at the cellular and organismic levels in Littorina littorea
}

\author{
Ionan Marigómez ${ }^{1}$, Mike P. Ireland ${ }^{2}$, Eduardo Angulo ${ }^{1}$ \\ ${ }^{1}$ Zitologi eta Histologi Laborategia, Biologia Zelularra eta Zientzia Morfologikoen Saila, Zientzi Fakultatea, Euskal Herriko \\ Unibertsitatea, 644 P. K., E-48080 Bilbo, Spain \\ ${ }^{2}$ Department of Biological Sciences, University College of Wales, Aberystwyth, Wales SY23 3DA, United Kingdom
}

\begin{abstract}
Winkles Littorina littorea were exposed to sublethal concentrations of cadmium (Cd) in the laboratory, and selective parameters indicative of bioavailable contamination and of environmental stress caused by sublethal pollution were calculated. Significant linear correlations were found between the $\mathrm{Cd}$ index and the following environmental stress indices: flesh condition index; mean epithelial thickness/mean diverticular radius and mean luminal radius/mean epithelial thickness of the digestive tubules; numerical density and surface density of digestive lysosomes. A significant linear regression was found in all cases, indicating that the changes in all the environmental stress indicators studied may be explained by changes in the organismic $\mathrm{Cd}$ index. It is concluded that such relationships could be applied to field studies in an attempt to estimate the presence of bioavailable contaminants and their effects on living organisms
\end{abstract}

\section{INTRODUCTION}

During recent decades phosphate fertilizers, incinerator waste, coal and oil combustion, and, most significantly, mining and industrial usage of cadmium (Cd), have resulted in an important increase of cadmium in the environment. $\mathrm{Cd}$ pollution, although hazardous, usually is of local importance (Ravera 1984).

Molluscs are known to concentrate $\mathrm{Cd}$ to a considerable degree over environmental levels (Scholz 1980, Marigómez \& Ireland 1990). This property makes them useful tools for monitoring $\mathrm{Cd}$ levels in coastal areas. Some problems concerning variability of heavy-metal concentration may lead to unreliable conclusions because metal concentration may depend on the state of health, growth rate, and reproductive stage of the populations, as well as on environmental factors such as salinity (Cossa \& Rondeau 1985, Phelps et al. 1985, Fischer 1986, Marigómez \& Ireland 1990). Since the metal concentration of molluscs can vary considerably due to variations in tiderably due to variations in soft body weight, Fischer (1983) introduced an alternative less variable parameter, shell weight. Subsequently, Marigómez \& Ireland (1990) concluded that the shell weight of winkles Littorina littorea (L.) is a reliable reference parameter to estimate tissue cadmium concentration values.

On the other hand, several authors have pointed out the necessity, when measuring the level of pollution within the marine environment, of an assessment of the biological effects of pollutants (Bayne 1980, Underwood \& Peterson 1988). Within this field, it has been demonstrated that a general stress response is induced by most pollutants under sublethal exposure conditions. It is qualitatively similar in quite different organisms, mainly at the lower levels of biological organization; however, this response may differ quantitatively depending on a wide spectrum of factors (Blackstock 1984). The non-specific stress response may be understood as the reaction of an organism to an environmental stimulus which, by exceeding a threshold value, disturbs normal organism function (Bayne 1985). This response may occur at all levels of biological organization from the community to molecular level (Sastry \& Miller 1981, Underwood \& Peterson 1988).

Quantitative cellular parameters indicative of a stress response have been used in some studies to assess the extent of the pollutant insult to organisms (Lowe et al. 
1981, Marigómez et al. 1986, Lowe 1988, Cajaraville et al. 1989). According to Moore (1986) the cellular response is prompt and highly sensitive to any change in the environment. In previous investigations $\mathrm{Cd}$ has been shown to provoke a measurable effect on the structure of digestive cells (Vega et al. 1989) and their lysosomal system (Marigómez et al. 1989) in experimentally exposed Littorina littorea. Such effects were dependant on the environmental concentration of the metal and on the exposure time.

Alterations in cell metabolism may lead to some effects at more complex levels of biological organization. The effects of metallic pollutants on growth of aquatic organisms was one of the first systems studied (Brown \& Ahsanullah 1971). Littorina littorea exposed to sublethal concentrations of $\mathrm{Cd}$ show a reduction in dry weight of the soft body dependant on the Cd concentration in the soft body (Marigómez \& Ireland 1990). In spite of the parallel between accumulation of pollutants and their effects on organisms, very few investigations have attempted to correlate both phenomena. Page et al. (1984) demonstrated that the activities of some specific enzyme systems are well correlated with metal burdens in the tissues of 2 bivalve species (Mytilus edulis and Mya arenaria). As a consequence, they concluded that these enzyme systems provided a useful sublethal stress indicator in these species that could aid in evaluating the adverse effects of metal inputs into the marine system.

The present investigation was undertaken to establish the association (by means of correlation analysis) and to estimate causability/predictibility (by regression analysis) between the biological effects of $\mathrm{Cd}$ at cellular and organismic levels, and the $\mathrm{Cd}$ index of Fischer (1983, 1984)

\section{MATERIALS AND METHODS}

Littorina littorea individuals (collected from Westport, 5352' N, $9^{\circ} 37^{\prime} \mathrm{W}$, Clew Bay, Eire, 1985) were purchased from a commercial dealer and transferred to the laboratory in Bilbao, Spain. Winkles measuring 20 to $23 \mathrm{~mm}$ in shell height were selected because shell weight $(\mathrm{g})$ and soft body dry weight $(\mathrm{mg})$ were linearly related within this size-class of sexually mature individuals (Marigómez \& Ireland 1990). Selected individuals were maintained in a 151 aquarium (16 ind. $\mathrm{l}^{-1}$ ) with filtered (glass wool plus active carbon) natural seawater (Zierbena, Biscay) for $1 \mathrm{wk}$, in the absence of food, in order to acclimate to laboratory conditions and to achieve standardization of physiological condition. Tanks were continuously aerated and water temperature ranged between 16 and $18^{\circ} \mathrm{C}$. Periwinkles were exposed to 2 sublethal concentrations of cadmium as $\mathrm{CdCl}_{2}\left(0.5\right.$ and $\left.1.25 \mathrm{mg} \mathrm{l}^{-1}\right)$ in 2 replicate series for $27 \mathrm{~d}$.
The higher concentration used represents the threshold of sublethal response (Marigómez et al. 1987), while the lower concentration of $\mathrm{Cd}$ is close to the value for the metal recorded in some highly polluted estuarine waters (Sprague 1986). One control series was also run. During the experimental period, specimens were continuously fed Fucus vesiculosus. Water and food were changed every second day.

After $4,6,10,13,17,20,24$ and $27 \mathrm{~d}$ exposure to $\mathrm{Cd}$, individuals were removed from experimental tanks to conduct: (1) a planimetric study of the digestive gland, (2) analysis of the metal content by atomic absorption spectrophotometry, (3) the calculation of the flesh condition index (FCI; Lobel \& Wright 1982). Samples for the stereological study of the structure of digestive lysosomes were taken at $3,6,10,14,18,22$ and $28 \mathrm{~d}$

To determine changes in the quantitative structure of digestive cells by means of planimetry, paraffin sections $(7 \mu \mathrm{m})$ of material fixed in Bouin's fluid were stained with PAS-alcian blue. The planimetric procedure described by Recio et al. (1988) and Vega et al. (1989) was applied. Five tubule sections were randomly selected in each of 5 sections of the digestive gland/ gonad complex ( $60 \mu \mathrm{m}$ distant from each other). Thus, 25 tubule sections were drawn per winkle with the aid of a drawing-tube attachment to a Nikon Optiphot microscope. Section profiles were recorded using a Watanabe DT1000 digitizer, and planimetric measures calculated by a Olivetti M240 personal computer. Thus, 5 parameters were obtained: mean epithelial thickness (MET), mean diverticular radius (MDR), mean luminal radius (MLR), MET/MDR ratio and MLR/MET ratio. Only these ratios, which are correlated with the 3 independent parameters, have been used in the present work because their values are dependant on external Cd concentration and exposure time (Vega et al. 1989).

Cadmium analysis was performed on samples of fresh tissues corresponding to between 10 and 12 individuals. Samples were rinsed in distilled water and dried at $105^{\circ} \mathrm{C}$ for $48 \mathrm{~h}$, digested in concentrated nitric acid (Aristar), diluted with $0.1 \mathrm{M}$ nitric acid and analyzed by atomic absorption spectrophotometry (Perkin-Elmer 2280) with simultaneous background correction and a sensitivity of $0.3 \mathrm{mg} \mathrm{l}^{-1}$. Standards were made up in $0.1 \mathrm{M}$ nitric acid within the concentration range 1 to $5 \mathrm{mg} 1^{-1}$. Cd was not found in control specimens (Marigómez \& Ireland 1989, 1990), so they have not been used for the present statistical investigation.

Soft body and shell dry weights were recorded to calculate the FCI (Lobel \& Wright 1982) and the Cd/ shell-wt index (Fischer 1983). The flesh condition is a field variable of physical performance (Lobel \& Wright 1982) and is calculated as $\mathrm{mg}$ flesh dry w $\mathrm{g}^{-1}$ shell dry wt. The Cd/shell-wt index (Fischer 1983) eliminates 
some of the variability in field records (Fischer 1984, 1986), and corrects the overestimation of $\mathrm{Cd}$ body burdens which occurs when Cd concentrations are used as measures of bioavailable metal (Marigómez \& Ireland 1990). It is calculated as $\mathrm{mg} \mathrm{Cd}$ in soft body $\mathrm{g}^{-1}$ shell dry wt.

The stereological study of the digestive lysosomal system was performed according to Lowe et al. (1981) and Cajaraville et al. (1989). Small pieces of freshly excised digestive gland/gonad complex were frozen with dichlorodifluoromethane $\left(-50\right.$ to $\left.-55^{\circ} \mathrm{C}\right)$ and stored at $-26^{\circ} \mathrm{C}$. Sections $(9 \mu \mathrm{m})$ were cut in a Bright's cryotome (5030 microtome) at a cabinet temperature of -28 to $-30^{\circ} \mathrm{C}$. The cytochemical reaction for $\beta$ glucuronidase was demonstrated in unfixed sections (Moore 1976, Cajaraville et al. 1989, Marigómez et al. 1989). After application of the stereological procedure described by Lowe et al. (1981) 4 parameters indicative of the structure of the digestive lysosomal system were calculated, namely: volume density (VD), surface density (SD), surface to volume ratio (S/V), and numerical density (ND). According to Marigómez et al. (1989), only SD and ND are dependant on the external concentration of $\mathrm{Cd}$ and exposure time, therefore only these 2 parameters have been used in the present investigation.

For statistical analysis, mean values corresponding to each experimental series $(n=2)$ by treatment and sampling-day were used as data. As 3 sets of data were missing, correlation and regression analyses were performed between 29 pairs of variable values ( 8 sampling days $\times 2 \mathrm{Cd}$ concentrations $\times 2$ replicate series $=32$ points). When correlating changes in digestive lysosomal structure with $\mathrm{Cd}$ index, statistical analysis was based on data interpolated from the function $\mathrm{Cd} /$ shell-wt index vs exposure conditions ( $\mathrm{Cd}$ concen- tration and time) obtained by Marigómez \& Ireland (1990). This was undertaken because samples had been taken on different experimental days due to procedural difficulties. Thus, the number of pairs of variable values used in this correlation/regression analyses was 20 since some of the replicate series samples were used as a single interpolated value. Statistical treatment was the SPSS/PC TM statistical package in the Olivetti M240 PC personal computer.

\section{RESULTS}

High concentrations of $\mathrm{Cd}$ were found in winkles exposed to both external metal concentrations. This led to $\mathrm{Cd} /$ shell-wt index values ranging from ca 3 to 40 . MET/MDR and MLR/MET values $(\times 100)$ ranged between ca 75 and 55, and ca 30 and 70 , respectively; and the values obtained for the FCI varied between ca 40 and 90 . Similarly, lysosomal ND values $(\times 1000)$ ranged between ca 30 and 10 , and SD values $(\times 10000)$ between ca 75 and 50 . These were the only transformations of data required to obtain variables of a comparable magnitude. The Cd/shell-wt index was significantly correlated $(\mathrm{p}<0.01)$ with all parameters indicative of environmental stress. A logit transformation of 1 or 2 of the variables analysed at each paired correlation test did not offer a more significant correlation, although the values of correlation coefficients corresponding to lysosomal FCI, ND and SD resulted in a slight increase after logit transformation of data (Table 1). A simple linear correlation model is sufficient to describe the covariance of each $\mathrm{Cd} /$ shell-wt index/ stress indicator parameter pair. It must be noted that parameters indicating the quantitative structure of digestive cells (MET/MDR and MLR/MET) offer the

Table 1. Littorina littorea. Linear and exponential correlation coefficients ( $\mathrm{r}$ ) between stress and cadmium body burden indicator parameters in winkles. Abbreviations are: (FCl) flesh condition index; (MET/MDR) mean epithelial thickness/mean diverticular radius; (MLR/MET) mean luminal radius/mean epithelial thickness; (ND) numerical lysosomal density; (SD) lysosomal surface density; Cd/shell wt index according to Fischer (1983)

\begin{tabular}{|c|c|c|c|c|c|c|}
\hline \multirow[t]{2}{*}{ Parameter } & \multicolumn{3}{|c|}{$\mathrm{Cd} /$ shell-wt index } & \multicolumn{3}{|c|}{$\ln (\mathrm{Cd} / \mathrm{shell}-\mathrm{wt}$ index $)$} \\
\hline & I & $\mathrm{df}$ & $\mathrm{p}$ & r & $\mathrm{df}$ & $\mathrm{p}$ \\
\hline FCI & 0.6175 & 27 & $<0.01$ & 0.5327 & 27 & $<0.01$ \\
\hline MET/MDR & $0.8402^{a}$ & 27 & $<0.01$ & 0.7535 & 27 & $<0.01$ \\
\hline MLR/MET & $0.7739^{\mathrm{a}}$ & 27 & $<0.01$ & 0.7053 & 27 & $<0.01$ \\
\hline ND & 0.7475 & 18 & $<0.01$ & 0.7378 & 18 & $<0.01$ \\
\hline $\mathrm{SD}$ & 0.6510 & 18 & $<0.01$ & $0.6892^{a}$ & 18 & $<0.01$ \\
\hline $\ln (\mathrm{FCI})$ & $0.6480^{a}$ & 27 & $<0.01$ & 0.5511 & 27 & $<0.01$ \\
\hline ln (MET/MDR) & 0.8360 & 27 & $<0.01$ & 0.7401 & 27 & $<0.01$ \\
\hline $\ln (\mathrm{MLR} / \mathrm{MET})$ & 0.7736 & 27 & $<0.01$ & 0.7329 & 27 & $<0.01$ \\
\hline $\ln (\mathrm{ND})$ & $0.7771^{\mathrm{a}}$ & 18 & $<0.01$ & 0.7411 & 18 & $<0.01$ \\
\hline $\ln (\mathrm{SD})$ & 0.6584 & 18 & $<0.01$ & 0.6785 & 18 & $<0.01$ \\
\hline
\end{tabular}


Table 2. Littorina littorea. Linear regression coefficients (b) and their standard deviation (sd), Y intercepts (a) and their standard deviation (sd), and statistical significance according to Fisher's F-test (Sokal \& Rohlf 1979) of the regression of stress indices vs Cd/ shell-wt index in winkles. See Table 1 for abbreviations

\begin{tabular}{|c|c|c|c|c|c|c|c|}
\hline & $\mathrm{df}$ & $b$ & sd & a & sd & $\mathrm{F}$ & $\mathrm{p}$ \\
\hline $\mathrm{FC}$ & 27 & -0.6732 & 0.1650 & 82.3362 & 3.5372 & 16.6427 & 0.0004 \\
\hline MET/MDR & 27 & -0.4008 & 0.0498 & 76.9122 & 1.0762 & 64.7963 & $<0.0001$ \\
\hline MLR/MET & 27 & 0.6961 & 0.1095 & 32.5490 & 2.3469 & 40.3086 & $<0.0001$ \\
\hline $\mathrm{ND}$ & 18 & -0.4929 & 0.1032 & 27.6281 & 2.2836 & 22.7897 & 0.0002 \\
\hline $\mathrm{SD}$ & 18 & -0.0633 & 0.0174 & 7.1232 & 0.3845 & 13.2398 & 0.002 \\
\hline
\end{tabular}

higher correlation values, the lowest value corresponding to the FCI. It is possible that this FCI value would have improved if higher numbers of specimens were sampled.

Results of the linear regression analysis are listed in Table 2 and illustrated in Fig. 1. The regression coefficient of each environmental stress parameter vs $\mathrm{Cd} /$ shell-wt index is significant. The significance checked by Fischer's F test (Sokal \& Rohlf 1979) is higher for MET/MDR and MLR/MET than for any other parameter (Table 2).

\section{DISCUSSION}

A key question in pollution research is to what extent the parameters employed to measure pollution also predict subsequent changes in other properties of the system (Underwood \& Peterson 1988). For instance, biochemical changes at the subcellular level in a target organism precede subsequent cell and tissue alterations, which in turn may later affect physiological function and ultimately, perhaps, certain population parameters (Underwood \& Peterson 1988).

The integration of physical, chemical and biological processes by means of environmental quality models enables the estimation of the assimilative capacity of polluted receiving waters (Widdows 1985). According to this author, some of the requirements of these quality models should be (1) identification of toxic contaminants, and (2) establishment of dose-response relationships for relevant pollutants and appropriate target organisms. In this context, the relevance of our investigation relies on the fact that we have found a significant linear correlation between the amount of bioavailable $\mathrm{Cd}$ and the amount of $\mathrm{Cd}$-induced stress response alteration at different levels of biological organization. It is especially interesting that association between contamination level and sublethal toxic effects caused by pollution is a simple linear response. Field studies are now required to state the relevance of these experimental results in the complex situation of the marine environment.
Although the lower correlation coefficient values found when associating FCI (organismic parameter) with $\mathrm{Cd}$ /shell-wt index might be attributed to limitations in sampling numbers, there may be a biological
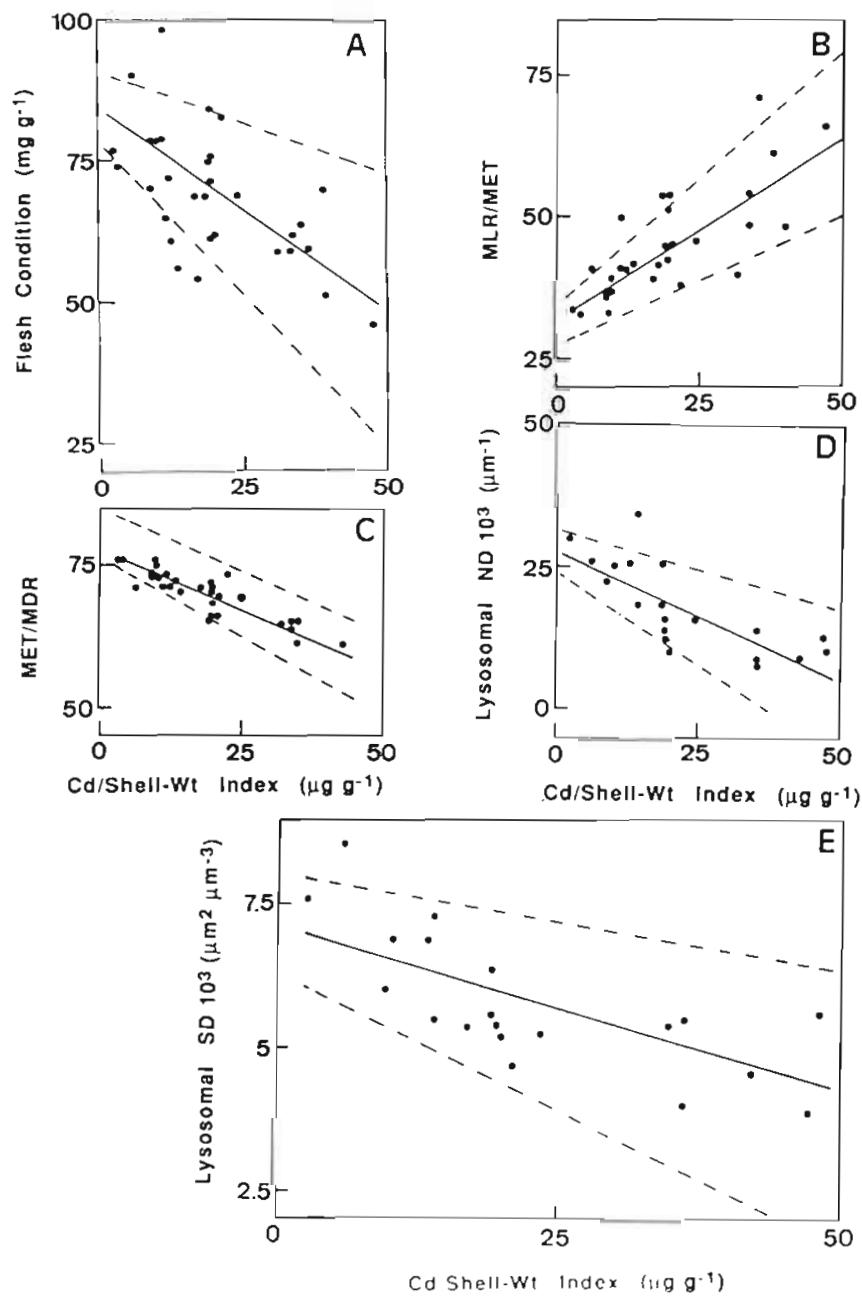

Fiq. 1. Littorna littorea. Linear functions explaining changes in: (A) flesh condition index; (B) mean luminal radius/mean epithelial thickness (MLR/MET); (C) mean epithelial thickness/mean diverticular radius (MET/MDR); (D) lysosomal numerical density; and (E) lysosomal surface density of winkles against $\mathrm{Cd}$ /shell-wt Index (Fischer 1983), after exposure to sublethal concentrations of $\mathrm{Cd}$. Dashed lines: $95 \%$ confidence intervals of regression function 
cause for this result. The effect of sublethal levels of $\mathrm{Cd}$ on the digestive lysosomal system is detectable after $4 \mathrm{~d}$ exposure to the present $\mathrm{Cd}$ concentrations (Marigómez et al. 1989) while the effect on the quantitative structure of digestive cells is observed $6 \mathrm{~d}$ after the beginning of exposure to the same Cd-concentrations (Vega et al. 1989). The effect on the physiological condition is only observed after $13 \mathrm{~d}$ exposure to $1.25 \mathrm{mg} \mathrm{Cd} \mathrm{l}^{-1}$ and after $24 \mathrm{~d}$ exposure to $0.5 \mathrm{mg} \mathrm{Cd} \mathrm{l}^{-1}$ (Marigómez \& Ireland 1990). Consequently, this delay in the stress response which depends on the complexity of the level of biological organization could be the reason for the lower correlation values found for the cases of the subcellular and the organismic responses. Perhaps the present experimental exposure time corresponds to the time taken for a response at the cellular/ tissue level more so than at the subcellular or the organismic level. Indeed, the lysosomal system may offer more significant changes at shorter times (Cajaraville et al. 1989), while the FCI seems to be responsive to longer periods of exposure to pollutants (Lobel \& Wright 1982).

Similar results have been obtained by Page et al. (1984), who found that $\mathrm{Cr}, \mathrm{Cu}$ and $\mathrm{Pb}$ concentrations are correlated with aspartate aminotransferase and glucose-6-phosphate dehydrogenase enzymatic activities, as well as with the condition index in various bivalve molluscs. Widdows \& Johnson (1988) indicated that the scope for growth may be related to hydrocarbon body burdens in mussels collected from 4 field stations. Widdows et al. (1981) found a significant inverse correlation between a biochemical index of environmental stress (Tau/Gly ratio) and the concentration of hydrocarbons in the tissues of mussels. Some other investigations (Widdows et al. 1982, Moore et al. 1984) have dealt with other correlations between distinct environmental stress parameters.

Clarke \& Green (1988) indicate that in relating observed biological responses to chemical causes, it must be accepted that field studies will always involve a large number of chemical compounds; most of these will covary very precisely. There will be little prospect of discriminating the effects of particular pollutants by purely statistical means because the biological responses are generalised, sublethal stress-measures, responsive to a wide variety of pollutants at the same time. However, in the present investigation a significant linear regression between sublethal levels of $\mathrm{Cd}$ expressed in standardized terms of bioavailable pollution and environmental stress indices has been demonstrated. This points out the possibility of distinguishing between the strength of various stressors in field studies on the basis of multiple regression of stress indices vs pollutant indices (analogous to the present $\mathrm{Cd}$ index) and their interactions.
When considering the possibility of the species Littorina littorea in ecotoxicological assessment of marine environment quality, Bakke (1988) outlined the importance of this species in boreal rocky shore communities, its wide geographical distribution, and that L. littorea represents a feeding type different from bivalve molluscs which are commonly used to monitor marine contamination. However, Bakke (1988) reported several difficulties when using physiological energetics of L. littorea in biological effects monitoring because factors regulating the energy conversion processes still remain insufficiently known. In a similar mode, histological studies have revealed that the structure and working of the digestive gland is distinct from that described in bivalve molluscs (Marigómez 1989, Soto et al. 1990). Taylor \& Andrews (1988) also described a particular mechanism of defense against environmental osmotic changes. Genetically, L. littorea presents very few polymorphic locci, and hence this represents a handicap in trying to obtain a genetic assessment of the development of tolerances to pollutants (Fevolden \& Garner 1987). Therefore, and in agreement with Bakke (1988), the present authors wish to point out the limited knowledge of genetics and bioenergetics of this species. Until these are known it cannot be concluded whether $L$. littorea may serve as an alternative and/or complementary sentinel species in marine pollution monitoring

Acknowledgements. The authors acknowledge the major assistance offered by M. M. Vega and M. P. Cajaraville. This work was financied in part by the Basque Government (Research Project X-86.041) and the University of the Basque Country (F. P. I. \& P. P. Grant, 1988).

\section{LITERATURE CITED}

Bakke, T (1988). Physiological energetics of Littorina littorea under combined pollutant stress in field and mesocosm studies. Mar Ecol. Prog. Ser. 46: 126-128

Bayne, B. L. (1980). Physiological measurements of stress. Rapp. P.-v. Réun. Cons. perm. int. Explor. Mer. 179: 56-61

Bayne, B. L. (1985). Responses to environmental stress: tolerance, resistance and adaptation. In: Gray, J. S., Christiansen, M. E. (eds.) Marine biology of polar regions and effects of stress on marine organisms. John Wiley \& Sons Ltd., New York, p. 331-349

Blackstock, J. (1984). Biochemical metabolic regulatory responses of marine invertebrates to natural environmental change and marine pollution. Oceanogr. mar. Biol. A. Rev. 22: 263-313

Brown, V. M., Ahsanullah, M. (1971). Effects of heavy metals on mortality and growth. Mar. Pollut. Bull. 2: 182-188

Cajaraville, M. P., Marigómez, J. A., Angulo, E. (1989). A stereological survey of lysosomal structure in Littorina littorea exposed to 1-naphthol. Comp. Biochem. Physiol. 93C: $231-237$

Clarke, K. R., Green, R. H. (1988). Statistical design and analysis for a 'biological effects' study. Mar. Ecol. Prog. Ser. 46: 213-226. 
Cossa, D., Rondeau, J. G. (1985). Seasonal, geographical and size-induced variability in mercury content of Mytilus edulis in an estuarine environment, a re-assessment of mercury pollution level in the estuary and gulf of St. Lawrence. Mar. Biol. 88: 43-49

Fevolden, S. E., Garner, S. P. (1987). Environmental stress and allozyme variation in Littorina littorea (Prosobranchia). Mar. Ecol. Prog. Ser. 39: 129-136

Fischer, H. (1983). Shell weight as an independent variable in relation to cadmium content of molluscs. Mar. Ecol. Prog. Ser. 12: 59-75

Fischer, H. (1984). Cadmium body burden/shell weight of mussels: a precise index for environmental monitoring. Comm. Meet. Int Coun. Explor. Sea C.M. ICES/E: 41: $1-19$

Fischer, H. (1986). Influence of temperature, salinity, and oxygen on the cadmium balance of mussels Mytilus edulis. Mar. Ecol. Prog. Ser. 32: 265-278

Lobel, P. B., Wright, P. A. (1982). Relationship between body zinc concentration and allometric growth measurements in the mussel Mytilus edulis. Mar. Biol. 66: 145-150

Lowe, D. M. (1988). Alterations in the cellular structure of Mytilus edulis resulting from exposure to environmental contaminants under field and experimental conditions. Mar. Ecol. Prog. Ser. 46: 91-100

Lowe, D. M., Moore, M. N., Clarke, K. R. (1981). Effects of oil in the digestive cells in mussels: quantitative alterations in cellular and lysosomal structure. Aquat. Toxicol. 1: 213-226

Marigómez, J. A. (1989). Aportaciones cito-histologicas a la evaluación ecotoxicológica de niveles subletales de cadmio en el medio marino: estudios de láboratorio en el gasterópodo prosobranquio Littorina littorea (L.). Ph. D. thesis, University of the Basque Country, Bilbao

Marigómez, J. A., Angulo, E., Moya, J. (1986). Copper treatment of the digestive gland of the slug Arion ater L. 2 . Morphometrics and histophysiology. Bull. envir. Contam. Toxic. 36: 608-615

Marigómez, J. A., Ireland, M. P. (1989). Accumulation, distribution and loss of cadmium in the marine prosobranch Littorina littorea. Sci. total Envir 78: 1-12

Marigómez, J. A., Ireland, M. P. (1990). A laboratory study of cadmium exposure in Littorina littorea in relation to environmental cadmium and exposure time. Sci. total Envir. 90: 75-87

Marigómez, J. A., Martin, L. M., Sáez, V. (1987). Lethal effects of $\mathrm{Cd}$ in Littorina littorea (L.) (Gastropoda, Prosobranchia). Cuad. Marisq. (Publ res téc. Cons. Pesca, Marisq. Cult. Mar. Xunta Galicia) 9: 181-189

Marigómez, J. A., Vega, M. M., Cajaraville, M. P., Angulo, E (1989). Quantitative responses of the digestive lysosomal system of winkles to sublethal concentrations of cadmium. Cell. mol. Biol. 35: 555-562

Moore, M. N. (1976). Cytochemical demonstration of latency of lysosomal hydrolases in digestive cells of the common mussel Mytilus edulis and changes induced by thermal stress. Cell. Tissue Res. 175: 279-287

Moore, M. N. (1986). Molecular and cellular indices of pollution. In: Giam, C. S., DOW, H. J. M. (eds.) Strategies and advanced techniques in marine pollution studies: Mediterranean Sea, Vol. 69 NATO-ASI Series, Berlin

Moore, M. N., Widdows, J., Cleary J. J., Pipe, R. K., Salkeld, P. N., Donkin, P., Farrar, S. V., Evans, S. V., Thomson, P. E.

This article was submitted to the editor
(1984). Responses of the mussel Mytilus edulis to copper and phenanthrene: interactive effects. Mar. environ. Res. 14: $167-183$

Page, D. S., Gilfillan, E. S., Hanson, S. G., Hotham, J. R., Foster, J. C. (1984). Correlation of body burden of heavy metals with physiological stress indicators in Mytilus edulis and Mya arenaria exposed to heavy metals in the field. Mar. environ. Res. 14: 505

Phelps, H. L., Wright, D. A., Mihursky, J. A. (1985). Factors affecting trace metal accumulation by estuarine oysters Crassostrea virginica. Mar. Ecol. Prog. Ser 22: 187-197

Ravera, O. (1984). Cadmium in freshwater ecosystems. Experientia 40: 2-14

Recio, A., Marigómez, J. A., Angulo, E., Moya, J. (1988). Zinc treatment of the digestive gland of the slug Arion ater L. II Sublethal effects at the histological level. Bull. envir. Contam. Toxic. 41: 865-871

Sastry, A. N., Miller, D. C. (1981). Application of biochemical and physiological responses to water quality monitoring. In: Vernberg, F. J, Calabrese, A., Thurberg, F. P., Vernberg. W. B. (eds.) Biological monitoring of marine pollutants. Academic Press, New York, p. 265-294

Scholz, N. (1980). Accumulation, loss and molecular distribution of cadmium in Mytilus edulis. Helgoländer Meeresunters. 33: 68-78

Scott, D. M., Major, C. W. (1972). The effect of copper (II) on survival, respiration and heart rate in the common mussel, Mytilus edulis. Biol. Bull. mar. biol. Lab., Woods Hole 143: 679-688

Sokal, R. R., Rohlf, F. J. (1979). Biometría. Ed. Blume, Madrid

Soto, M. Agirregoikoa, M. G., Pérez, M. A., Marigómez, J. A. (1990). A planimetric study of the variability in digestive diverticular morphology of Littorina littorea (Linnaeus) and Mytilus edulis (Linnaeus). J. moll. Stud. 56: (in press)

Sprague, J. B. (1986). Toxicity and tissue concentrations of lead, zinc and cadmium for marine molluscs and crustaceans. Int. Lead Zinc Res. Organ. Inc., North Carolina, p. 215 .

Taylor, P. M., Andrews, E. B. (1988). Osmoregulation in the intertidal gastropod Littorina littorea. J. exp. mar. Biol. Ecol. 122: 35-46

Underwood, A. J., Peterson, C. H. (1988). Towards an ecological framework for investigating pollution. Mar. Ecol. Prog. Ser. 46: 227-234

Vega, M. M., Marigómez, J. A., Angulo, E. (1989). Quantitative alterations in the structure of the digestive cell of Littorina littorea on exposure to cadmium. Mar Biol. 103: $547-553$

Widdows, J. (1985). Physiological responses to pollution. Mar. Pollut. Bull. 16: 129-134

Widdows, J., Bakke, T., Bayne, B. L., Donkin, P., Livingstone, D. R., Lowe, D. M., Moore, M. N., Salked, P. N. (1982). Responses of Mytilus edulis on exposure to the water accommodated fraction of North Sea oil. Mar. Biol. 67: $15-31$

Widdows, J., Bayne, B. L., Donkin, P., Livingstone, D. R., Lowe, D. M., Moore, M. N., Salkeld, P. N. (1981). Measurement of the responses of mussels to environmental stress and pollution at Sullon Voe: a base-line study. Proc. R. Soc. Edinb. (Sect. B) 80: 323-383

Widdows, J., Johnson, D. (1988). Physiological energetics of Mytilus edulis: Scope for Growth. Mar. Ecol. Prog. Ser. 46: $113-121$

Manuscript first received: March 12, 1990

Revised version accepted: July 6, 1990 